Portland State University

PDXScholar

1979

\title{
Factors involved in the utilization of a divorce counseling service
}

Jean G. DeMaiffe

Portland State University

Richard H. Weiss

Portland State University

Follow this and additional works at: https://pdxscholar.library.pdx.edu/open_access_etds

Part of the Counseling Commons, and the Interpersonal and Small Group Communication Commons Let us know how access to this document benefits you.

\section{Recommended Citation}

DeMaiffe, Jean G. and Weiss, Richard H., "Factors involved in the utilization of a divorce counseling service" (1979). Dissertations and Theses. Paper 2745.

https://doi.org/10.15760/etd. 2738

This Thesis is brought to you for free and open access. It has been accepted for inclusion in Dissertations and Theses by an authorized administrator of PDXScholar. Please contact us if we can make this document more accessible: pdxscholar@pdx.edu. 
FACTORS INVOLVED IN THE UTILIZATION

OF A DIVORCE COUNSELING SERVICE

by

JEAN G. DEMAIFFE and RICHARD H. WEISS

A research practicum submitted in partial

fulfillment of the requirement

for the degree of

MASTER OF SOCIAL WORK

Portland State University

1979

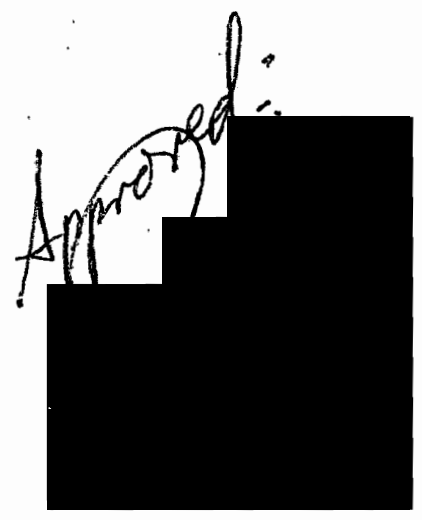




\section{ACKNOWLEDGEMENTS}

The authors of this report would like to thank the Staff of the Clackamas County Family Court Service for their assistance and Karin Weiss. and Tiffany Weiss for their patience and support. 
TABLE OF CONTENTS

PAGE

ACKNOWLEDGEMENTS

CHAPTER

I STATEMENT OF THE PROBLEM. . . . . . . . . . . . .

Section I: Introduction: Purpose of the Study ................. 1

Section II: Background ............. 1

Section III: IDCAP: A Study of Clackamas

County Divorces and its Influence on

the Development of a Family Court

Service .. . . . . . . . . . . .

Section IV: Clackamas County Family

Court Service: A Description . . . . . .

Section V: Research and the Clackamas

County Family Court Service . . . . . . .

Section VI: The Problem: Who is Being

Served?................ 6

II METHODOLOGY . . . . . . . . . . . . . 7

Section I: Overview ............. 7

Section II: Age................ 9

Section III: Length of Marriage . . . . . . . 9

Section IV: Employed Income . . . . . . . . 10

Section V: People Talked To . . . . . . . . . 11

Section VI: Sex.............. 12 
CHAPTER

PAGE

Section VII: Number of Children . . . . . .

Section VIII: Education . . . . . . . . .

Section IX: Referral Source...........

III

FINDINGS . . . . . . . . . . . . . . . .

Section I: Overview...............

Section II: Age . . . . . . . . . . . .

Section III: Length of Marriage.........

Section IV: Employed Income . . . . . . . . 17

Section V: People Talked To . . . . . . . . 19

Section VI: Sex.............. . . 25

Section VII: Number of Children . . . . . . 25

Section VIII: Education . . . . . . . . 26

Section IX: Referra1 Source .......... 27

IV DISCUSSION . . . . . . . . . . . . . . 30

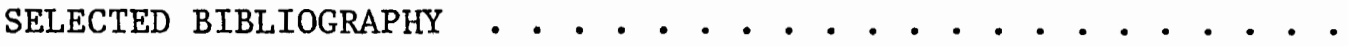




\section{LIST OF TABLES}

TABLE

PAGE

I Length of Marriage . . . . . . . . . . . . . 17

II Employed Income . . . . . . . . . . . . . . . . 18

III People Talked To . . . . . . . . . . . . . . 19

IV A Helpfulness of People Talked To

$\begin{aligned} & \text { IV B Helpfulness of People Talked To } \\ & \text { Psychologist . . . . . . . . . . . . . } 20\end{aligned}$

$\begin{aligned} & \text { IV C Helpfulness of People Talked To } \\ & \text { Marriage \& Family Counselor . . . . . . . . . . } 20\end{aligned}$

IV D Helpfulness of People Talked To

Social Worker ............... 21

IV E Helpfulness of People Talked To

IV F Helpfulness of People Talked To

IV G Helpfulness of People Talked To

IV $\mathrm{H}$ Helpfulness of People Talked To

IV I Helpfulness of People Talked To Friends . . . . . . . . . . . . . . 22

IV J Helpfulness of People Talked To Other . . . . . . . . . . . . . . . . . .

IV $\mathrm{K}$ Helpfulness of People Talked To No One and No Response . . . . . . . . 23

IV L Helpfulness of People Talked To Total Responses . . . . . . . . . . . . . 
V Number of Children . . . . . . . . . . . . 26

VI Years of Education . . . . . . . . . . . . 27

VIII Referral Sources: Served Group . . . . . . . . . 28 
CHAPTER I

STATEMENT OF THE PROBLEM

This chapter contains an introduction to the purpose of the study, a brief literature review on the need for divorce counseling, a description of a longitudinal study on divorce and the study's influence on the development of a family court service, and a description of Clackamas County Family Court Service with an analysis of its commitment to research.

SECTION I: INTRODUCTION: PURPOSE OF THE STUDY

This report presents a descriptive study of characteristics of persons using a family court service. A comparison is made between persons using the service and a sample of the population whom the agency was designed to serve.

The purposes of the study were to determine if the agency was serving the client population it was designed to serve and to provide a socio-demographic data base for further research and planning at the agency.

\section{SECTION II: BACKGROUND}

The following is a brief literature review to acquaint the reader with the theoretical background out of which the Clackamas County Family Court Service emerged. 
Numerous studies have pointed to the distress experienced by divorcing persons (Goode 1956; Gurin, Veroff \& Field 1960; Westman 1970; Weiss 1975; Campbe11, Converse \& Rodgers 1976; Hetherington, Cox \& Cox 1976; Jones 1977; Kitson 1977).

Much has been written on the negative impact of divorce on children (Despert 1953: McDermott 1968, 1970; Westman 1970, Wallerstein \& Ke11y 1974, 1975, 1976, 1977). On the other hand some studies (Nye 1957; Landis 1960) would indicate that over time, in the words of one researcher,

Children from happy marriages are better adjusted than children from divorced families, but those from divorced parents are better adjusted than those from parents whose marriages are intact but unhappy.... (Udry 1971)

Most studies have directly or indirectly pointed to constructive parent-parent and parent-child relationships as the most significant factors in the satisfactory adjustment of the children to divorce.

The Wallerstein \& Kelly and Hetherington studies indicate that the first year after divorce is the most stressful for both parents and their children. Furthermore, other sources (Kressel, Lopez-Morillas, Weinglass \& Deutsch 1978) conclude that the adversarial nature of the 1awyer-run divorcing process probably further contributes to the distress of the divorcing parties. They also conclude that the adversarial court process is ineffective as a resource for conflict resolution. They cite the Hetherington, Cox \& Cox study for how poorly court decreed visitation agreements are kept; they cite Jones, Gordon \& Sawhi11 (1976) for the low compliance with court ordered child support agreements; and they cite Cavanagh \& Rhode (1976) on the insufficient and inadequate quality of divorce settlements. 
According to Kressel, et al., non-adversarial models are beginning to emerge (Coogler 1977; Kressel, Deutsch, Jaffe, Tuchman \& Watson 1977; Lightman \& Irving 1976; Wallerstein \& Kelly 1977). Wallerstein \& Kelly propose a time-limited (six-session), crisis-oriented service that is "child centered, preventative, and planning oriented" (Wallerstein \& Kelly 1977).

Counseling services for divorcing persons have primarily been provided by Family or Conciliation Courts. Kressel, et al. in their analysis of the need have noted that historically these services have attempted to reconcile marriages rather than assist those wishing to end them in resolving the numerous issues inherent in the divorcing process.

\section{SECTION III; IDCAP: A STUDY OF CLACKAMAS COUNTY DIVORCES AND ITS INFLUENCE ON THE DEVELOPMENT OF A FAMILY COURT SERVICE}

In 1976 the Clackamas County Family Court Service was established by the Circuit Court in Clackamas County Oregon. The Family Court Service developed out of an awareness on the part of the Circuit Court and County Juvenile Department that some sort of resource was needed to provide assistance to the expanding divorcing population of Clackamas County. In 1975 an LEAA funded longitudinal study of divorcing parents and their children was initiated in Clackamas County, Divorce: Its Impact on Parents and Children (IDCAP), (Cohen 1978). Among questions found in the IDCAP study were four directly related to the estahlishment of a court sponsored counseling service (see IDCAP questions numbered 66, 67, $68,69)$. Respondents were asked if they could have used or would use a 
court counseling service wherein parents could work out a parenting relationship that would be most beneficial for their children. A majority of respondents indicated that they would have found such a service helpful and would use this service if it were available. The authors of IDCAP and the Circuit Court concluded from the study that a public divorce counseling service was needed to assist the population studied.

The service was designed to help divorcing parents resolve issues in their divorce and ongoing parenting relationship so that the children of the divorcing parents would be least negatively affected by the divorcing process.

SECTION IV: CLACKAMAS COUNTY FAMILY COURT SERVICE:

A DESCRIPTION

The Family Court Service was designed to meet the following goals and objectives: To provide short-term, individual, conjoint and group counseling to couples contemplating and/or involved in divorce proceedings. Objectives include helping parents to constructively resolve custody, visitation, and child support issues; assisting in the development of cooperative parenting relationships, whether married or divorced; providing advocacy for children of divorcing families; and, when appropriate, facilitating the avoidance of unnecessary divorces.

The Family Court Service is available to Clackamas County families who are considering, have filed for, or have completed divorce proceedings. Families with minor children are the agency's highest priority. Participation is voluntary and confidential. Custody studies are not done at the Family Court Service and counselors may not be subpoenaed to testify in court regarding cases. The object of the service is to 
provide a protected, non-adversarial environment for the resolution of issues inherent in the divorcing process.

Families are charged a $\$ 35.00$ fee for utilization of the Family Court Service. Since Ju1y 1, 1976, the $\$ 35.00$ fee is a part of the divorce filing fee for all persons filing for divorce in Clackamas County. Those families filing for divorce after July 1, 1976 have their fees paid automatically at the time of filing. Those families who filed before July 1, 1976, must pay the the $\$ 35.00 \mathrm{fee}$, unless waived, out of their pocket.

Families utilizing the service generally are assigned to one staff member who works with the family through the usual six to eight counseling sessions. SECTION V: RESEARCH AND THE CLACKAMAS COUNTY
FAMILY COURT SERVICE

The Clackamas County Family Court Service grew out of a research project and continues its investment in research and evaluation. In its short life, agency staff have participated not only in the ongoing IDCAP study but also in a client satisfaction survey, A Consumer Evaluation of the Clackamas County Family Court Service (Lee \& Watne 1978) and a parental perception study, Parental Perceptions of Behavioral Changes in Children Following Divorce (Borr 1978). Currently another study is being designed to determine the cost and service effectiveness of mandating certain types of cases through the Family Court Service (targeted to begin July 1, 1979). If this study is implemented as designed, the agency staff would nearly double in size and would be comprised of about an equal number of research and counseling staff. 
Its authors conclude, from the agency's history of research and evaluation, its support of this study, and the planned study, that the Family Court Service has been and is heavily invested in research and evaluation.

SECTION VI: THE PROBLEM: WHO IS BEING SERVED?

The authors reasoned that the above studies did not address the important issue of whether or not the Agency is serving its target population.

According to Gilbert \& Specht (1974), and others (Piven \& Cloward 1971; Moles, Hess \& Fascione 1968; Harrington 1962), many persons deemed in need of services may not avail themselves of existing social services and, further, that many persons in need of social services can be reached only by special delivery methods.

The Family Court Service Director, Nolan Jones, and Family Court Service Research Assistant, Donna Ricketts, agreed that the question the authors were interested in was significant to them in their planning process. Further, they asserted that the previous studies did not provide an adequate client demographic data base for their proposed mandated client study, and suggested that the authors' study could in part provide the client demographic data base required for that study. The authors confirmed that this data base would be included in the scope of their study. 
CHAPTER II

METHODOLOGY

SECTION I: OVERVIEW

As noted above, we chose for our first group (hereinafter referred to as the Surveyed Group, $N=114$ ), a systematic sample derived from the IDCAP study. For consistency, we obtained information from all those files which contained a completed interview schedule. Data for our contrast group (hereinafter referred to as the Served Group, $N=139$ ) was obtained from the closed case files of clients served at the Agency during the period July 1976 through November 1978. A copy of the Data Collection Schedule is included in the Appendix. We matched the Served Group with the Surveyed Group on the following three criteria used in the IDCAP study: 1) cases chosen were only those of clients who had filed for divorce and whose final decree was not entered at the time they filled out the Intake Application, 2) clients were divorcing from their first marriage, and 3) clients had at least one minor child from this first marriage.

It should be noted that the Surveyed and Served Groups are not mutually exclusive. Some people in the Surveyed Group chose to utilize the service when it became available and therefore became part of the Served Group as well. The comparability of the samples may be compromised as a result of the overlap of the samples. However, it can be argued that there is some logic to this procedure in that the majority 
of the Surveyed respondents indicated that they would use such a service were it available and the Agency has not been in existence long enough to develop a large enough data base to provide mutually exclusive populations from which samples could be drawn.

Files in both samples contained information from forms filled out separately by the mother and father. Thus, in the Served sample, if the father was divorcing from his second marriage, data on him would not be used; while if his wife were divorcing from her first marriage, data on her would be used.

Six of the variables discussed herein (age, length of marriage, employed income, sex, number of children, and education) were chosen using two criteria: 1) the data should be demographic in nature; and 2) the data should be available in the files of both the Surveyed and Served Groups.

A seventh variable (people talked to about the problems leading to petition) was included because the authors felt this might offer the Agency information on future referral sources and areas of outreach. This information was also readily available from the files of both Surveyed and Served Groups.

The eighth and final variable (referral source) was included to determine who, in fact, referred respondents to the Agency and, again, to provide information for use in future outreach efforts.

Chi squares were computed to compare the Surveyed and Served Groups on each of the separate variables except that of referral source, since data on this variable was only available for the Served Group. For the referral source, percentages of referral categories were computed from the total responses. In addition, the authors calculated chi squares for sub-variables of the variable of persons talked to. 
SECTION II: AGE

For the Surveyed Group, age was determined by observing the "age" box on the Petition for Dissolution of Marriage form, which form was always included in the respondent's file. For the Served Group, when there was no copy of the Petition in the file, age was determined by subtracting the client's date of filing for divorce (available on the Intake Application) from the client's date of birth (also available on the Intake Application). This was done to insure that ages for both the Surveyed and Served Groups would be their age at the time of Petition for Dissolution.

Ages were computed in full year increments such that a person born in December of 1946 and filing for divorce in December of 1976 would be rated as aged 30 years at time of filing the petition; whereas one born in December of 1946 and filing in November of 1976 would be rated as age 29 years.

\section{SECTION III: LENGTH OF MARRIAGE}

For the Surveyed Group, length of marriage was determined by subtracting the date of marriage from the date of Petition for Dissolution of Marriage (both available on the Petition). For the Served Group, length of marriage was determined by the same means except when no Petition was available in the file. In the latter case, date of marriage and date of petition were taken from the Intake Application form from sections as follows:

Have you filed for divorce _ No __ Yes
Date
Date of Marriage 
Length of marriage was also computed in full year increments, such that a person married in December of 1946 and filing for divorce in December of 1976 would be rated as married 30 years; whereas one born in December of 1946 and petitioning for divorce in November of 1976 would be considered to be married 29 years.

\section{SECTION IV: EMPLOYED INCOME}

For the Surveyed Group, employed income was determined by observing the response to the following items on the Interview Schedule:

9. Are you current1y working?

Yes, No.

If YES, are you working

Full time, Part time, Other (describe)

11. IF YOU ARE WORKING, what is your monthly income before anything is taken out? less than $\$ 200$, $\$ 200-399$, $\$ 400-599$, _ $\$ 600-799$, \$800-999, $\$ 1200-1399$, \$1000-1199, \$1600-1799, \$1400-1599, $\$ 1800 \&$ up

For the Served Group, this data was obtained from responses to the following questions on the Intake Application:

2. Work situation (check one)

Employed full time

Employed part time Unemployed

Retired

Student

Homemaker

Other:

3. Month1y Income:

(Before anything is taken out): 
To whom respondents spoke with about their problems was determined from the Surveyed Group by their responses to item 26 on the Interview Schedule:

26. (a) Since the divorce was filed, have you talked with anyone concerning the things that led you and your spouse to file? Yes No

(b) IF "YES": Who have you talked to about these problems? Have they been helpful or not helpful?

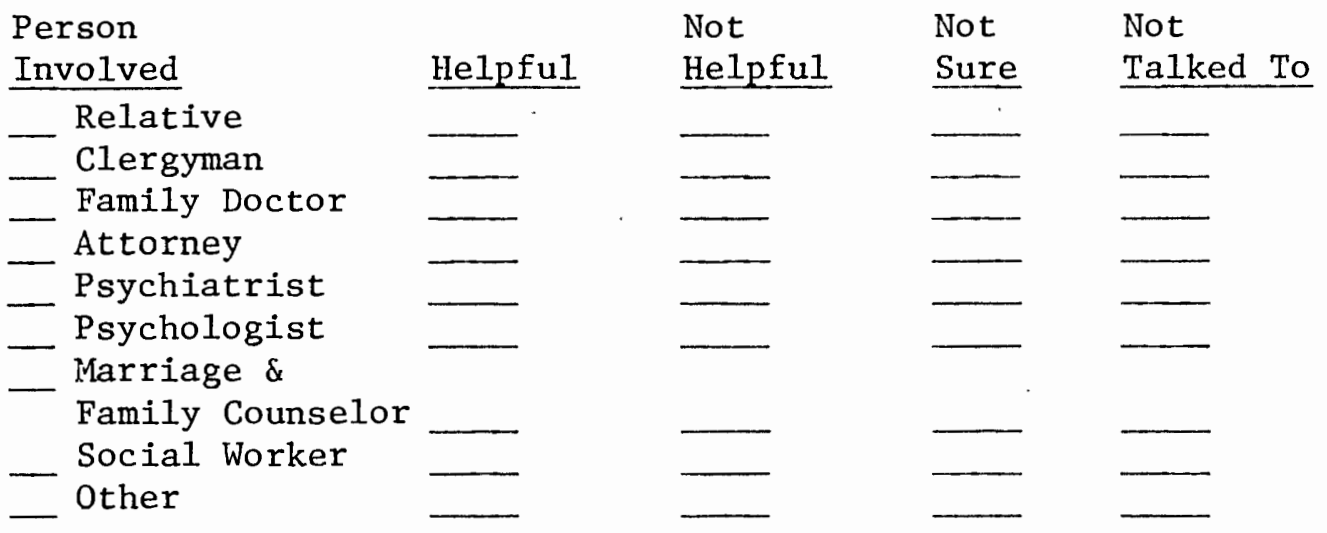

For the Served Group, the determining item was number 4 on the Intake Application:

4. (a) Since the possibility of divorce was raised, have you talked with anyone concerning your problems? Yes No

(b) IF "YES": Who have you talked to about these problems and have they been helpful?

Person talked to:

$\begin{array}{lll}\text { Helpful } & \text { Not } & \text { Not } \\ \text { Helpful } & \text { Sure }\end{array}$

\footnotetext{
Relatives Clergyman Family Doctor Attorney

Psychiatrist

- Psychologist

- Marriage \& Family Counselor Social Worker

- Other:
} 
While we have chosen to deal with the responses to these two questions as though they were identical, we realize that they are not. The question asked of the Surveyed Group is more specific and covers a shorter time period. Also, the Surveyed Group is asked "...have they (people talked to) been helpful or not helpful?"; whereas the Served Group was asked on1y."...have they been helpful?". However, this secondary difference is mitigated by the range of offered responses which includes both helpful and not helpful for both groups.

Another difference between these questions is that the Surveyed Group was offered a response category entitled "Not talked to". It is the authors' opinion that this difference is not significant since the respondents checked the "Not talked to" blanks only when they did not check the "person involved".

\section{SECTION IV: SEX}

Sex was determined for the Surveyed Group by noting the case number on the file, which number included a digit indicating sex of respondent, the number one (1) indicating male and the number two (2) designating female. For the Served Group, sex was determined by observing the response to the first statement on the Intake Application:

"Application filled out by ___ Mother ___ Father."

\section{SECTION VII: NUMBER OF CHILDREN}

For both groups, information was obtained on the number of children from the present marriage only. For the Surveyed Group, number of children was obtained from the Petition for Dissolution of Marriage. 
For the Served Group, if the Petition was not available, the information was obtained from the Intake Application in the following form:

Children of present marriage: Name

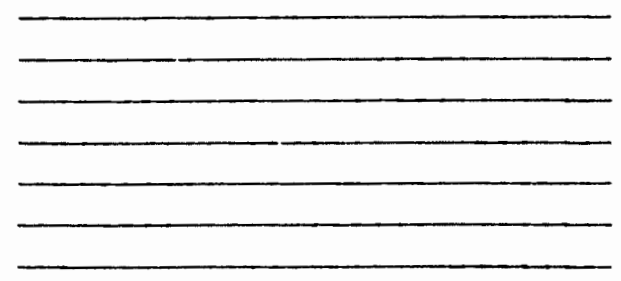

SECTION VIII: EDUCATION

The questions from which we obtained the educational attainment of respondents were different on the Intake Application and the Interview Schedule forms. The Interview Schedule (for the Surveyed Group) asked :

6. (a) How many years of school have you attended? Less than 4 years of high school Four years of high school 1-3 years of college 4 years of college 5 or more years of college

The Intake App1ication asked:

6. Education.

Years completed $1-11 \quad 12 \quad 13-15 \quad 16 \quad 17+$

The authors considered these two options to be essentially the same.

SECTION IX: REFERRAL SOURCE

Since the Surveyed Group was interviewed during the pre-agency period, data on referral source was taken only from the Served Group. To determine the referral source, the authors observed responses to the 
following question, available on the first page of the Intake Application:

Referred by clergyman Self School Lawyer Physician Court Other:

In summary, the methodology consisted primarily of identifying and recording significant variables and seeking to minimize any which might be confounding. Both samples were systematic samples matched for availability of data, status of divorce, and presence of a minor child or children. The two cases of overlap, discovered late in the study, do not appear to compromise the independence of the samples, given the small amount of overlap and the level of significance in differences found between the two groups. 
CHAPTER III

FINDINGS

This chapter presents descriptive findings derived from the comparison of the Surveyed and Served Groups. Section I includes a summary of the overall findings. Sections II through IX present an individual analysis of each variable addressed.

\section{SECTION I: OVERVIEW}

Overall, there were small, yet statistically significant, differences between the Surveyed and the Served Groups in three areas: 1) age of respondents, 2) number of years married, and 3) people talked to about their problems. Specifically, the people who were served by the Agency tended to be somewhat older and married slightly longer, and to be less likely to have talked with their friends and more likely to have talked to an attorney about their problems than those in the Surveyed Group. In four other areas (employed income, sex, number of children, and education) there was no significant difference between these two groups. Regarding who referred the Served Group to the Agency, respondents most frequently named attorneys.

SECTION II: AGE

The ages of the Surveyed Group ranged from 16 through 48 and of the Served Group from 16 through 54. The median age of the Surveyed 
Group was 29.7 and of the Served Group 32.9. At the .01 level of confidence, the difference between these two groups was significant $\left(\mathrm{df}=1, \mathrm{x}^{2}=6.82\right)$.

While the difference in age between the Surveyed and Served Groups was statistically significant, chronologically it is a very small difference--slightly more than three years (the Served Group being the older). Both groups are still in basically the same age category, late twenties/early thirties. People of these two age groups might have been in high school or college at the same time and may have had many of the same life issues to deal with especially in terms of attitudes toward divorce and counseling. So, again; while the difference in age was statistically significant, it may be effectively insignificant.

\section{SECTION III: LENGTH OF MARRIAGE}

The range of years married was divided into six subgroups: less than two years, three through five years, six through ten years, 11 through 15 years, 16 through 20 years, and more than 20 years. The median number of years married for the Surveyed Group was 8.95 and for the Served Group 10.25. At the .05 level of confidence, there was a significant difference between these two groups $\left(\mathrm{df}=5, \mathrm{x}^{2}=12.90\right)$. Table I shows the range of number of years married. 
TABLE I

LENGTH OF MARRIAGE

Surveyed Group

Served Group

Years Married Number Percent Chi Squares Number Percent Chi Squares

less than 2

$8 \quad 7.0$

$3-5$

27

23.7

.369

.000

$14 \quad 10.0$

.303

$6-10$

$37 *$

32.4

2.709

33

$11-15$

$\begin{array}{ll}27 & 23.7\end{array}$

$16-20$

$7 \quad 6.1$

more than 20

.124

3.817

$26 *$

23.7

.000

Total

.114

29

18.7

2.143

.101

$8 \quad 7.0$

$114 \quad 99.9$

25

20.9

3.131

$12 \quad 8.6$

.093

*Intra-group

Median Category

As with the variable of age, the difference between the Surveyed and Served Groups is statistically significant, but effectively quite smal1; the Served Group was married just over one year longer than the Surveyed Group. Speaking only in terms of number of years married, one might again expect both groups to be dealing with similar marital life issues.

\section{SECTION: IV: EMPLOYED INCOME}

Employed income was divided into eight subgroups: 1ess than $\$ 400$, five increments of $\$ 200$ each from $\$ 400$ through $\$ 1399$, $\$ 1400-\$ 1799$, and $\$ 1800$ or more. Those who responded that they were not employed (Surveyed $=28.9$ percent, Served $=26.6$ percent) and those who did not respond to this question at all (Surveyed $=1.8$ percent, Served $=3.6$ percent $)$ were not included in our statistics. The difference between these two unincluded groups was not significant at the .05 level of confidence $\left(\mathrm{df}=1, \mathrm{x}^{2}=.073\right)$. 
The median income of the Surveyed Group was $\$ 866$ per month and for the Served Group it was $\$ 686$. The difference between the two groups was not significant at the .05 level of confidence $\left(\mathrm{df}=7, \mathrm{x}^{2}=13.958\right)$. Table II below shows the distribution of employed income.

TABLE II

EMPLOYED INCOME

Surveyed Group Served Group

Employed Income Number Percent Chi Squares Number Percent Chi Squares

\begin{tabular}{lrrrrrr} 
less than $\$ 400$ & 9 & 11.4 & .000 & 11 & 11.3 & .000 \\
$\$ 400-599$ & 15 & 19.0 & .002 & 18 & 18.6 & .002 \\
$\$ 600-799$ & 12 & 15.2 & .697 & $22 *$ & 22.7 & .568 \\
$\$ 800-999$ & $9 *$ & 11.4 & .246 & 8 & 8.2 & .200 \\
$\$ 1000-1199$ & 13 & 16.5 & 2.345 & 6 & 6.2 & 1.909 \\
$\$ 1200-1399$ & 12 & 15.2 & 1.018 & 8 & 8.2 & 1.104 \\
$\$ 1400-1799$ & 4 & 5.1 & 2.404 & 15 & 15.4 & 1.958 \\
$\$ 1800$ or more & 5 & 6.3 & .262 & 9 & 9.3 & .214 \\
Total & 79 & 100.1 & & 97 & 99.9 & \\
\hline
\end{tabular}

*Intra-group

Median Category

There is a weakness in the findings regarding employed income in that the samples used for comparison were drawn during different time periods. Inflation during this time has been a much-talked-about factor in people's lives; however, the authors did not add an inflation factor into their calculations. Had such a factor been added in, the effect would have been to increase the difference in income between the groups. In that case the difference in incomes might have been significant. 
SECTION V: PEOPLE TALKED TO

There were statistically significant differences in people respondents talked to in two different categories. Specifically, the Surveyed Group was more likely to have talked to friends $\left(\mathrm{df}=1, \mathrm{x}^{2}=29.362\right.$, level of confidence $\left.=.001\right)$ and were less 1ikely to have talked to an attorney $\left(\mathrm{df}=1, \mathrm{x}^{2}=6.184\right.$, level of confidence $\left.=.02\right)$ than the Served Group.

TABLE III

PEOPLE TALKED TO

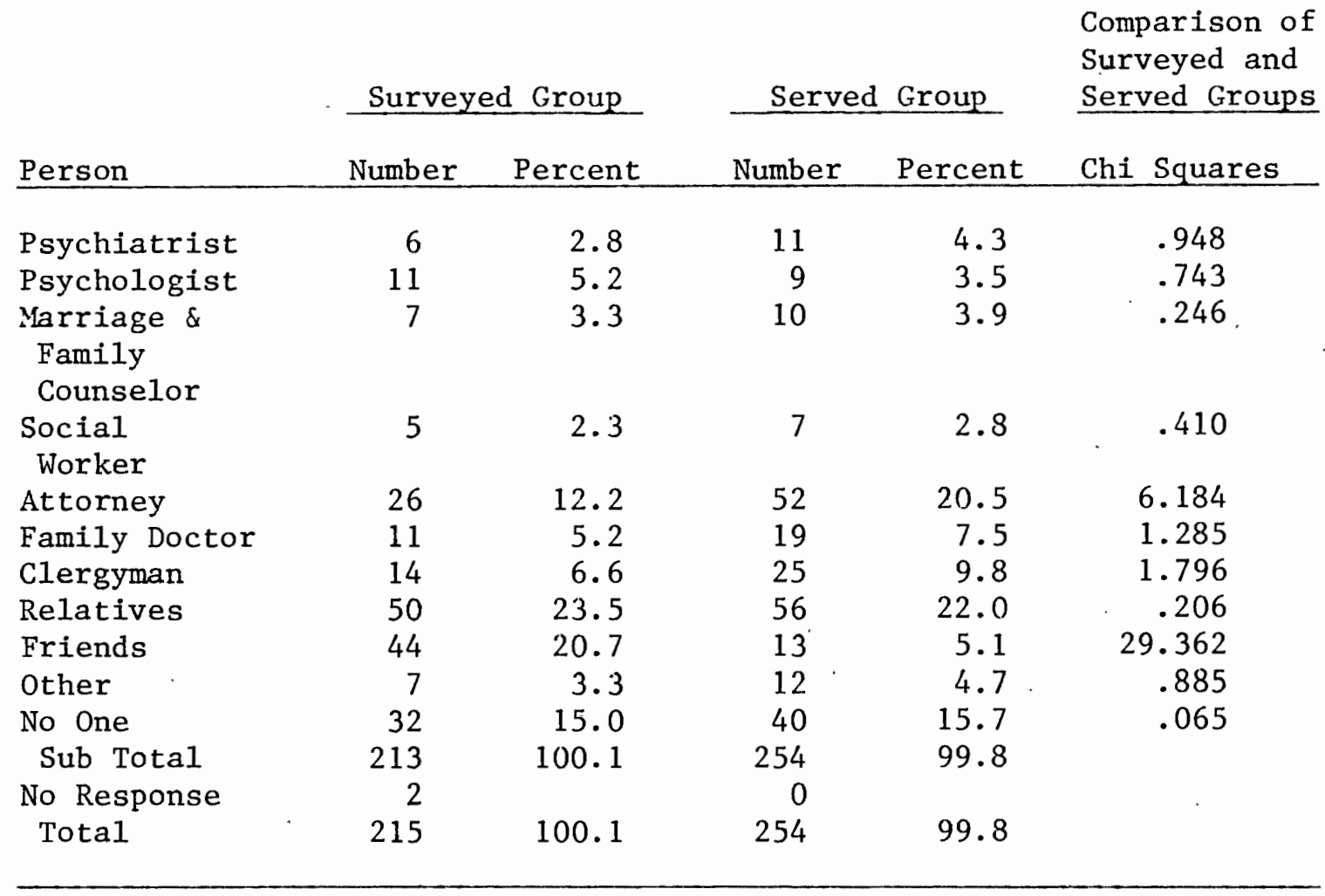


TABLE IV A

HELPFULNESS OF PEOPLE TALKED TO

PSYCHIATRIST

Surveyed Group Served Group

Number Percent Number Percent

\begin{tabular}{lrrrr} 
Helpful & 5 & 83.3 & 6 & 54.5 \\
Not Helpful & 0 & $-0-$ & 5 & 45.5 \\
Not Sure & 1 & 16.6 & 0 & $-0-$ \\
Not Rated On & 0 & $-0-$ & 0 & $-0-$ \\
$\quad$ Helpfulness & & 99.9 & 11 & 100.0 \\
\hline
\end{tabular}

TABLE IV B

HELPFULNESS OF PEOPLE TALKED TO PSYCHOLOGIST

Surveyed Group Served Group

Number Percent Number Percent

\begin{tabular}{lrccc} 
Helpful & 11 & 100.0 & 6 & 66.7 \\
Not Helpful & 0 & $-0-$ & 1 & 11.1 \\
Not Sure & 0 & $-0-$ & 1 & 11.1 \\
Not Rated On & 0 & $-0-$ & 1 & 11.1 \\
$\quad$ Helpfulness & & & & \\
Total & 11 & 100.0 & 9 & 100.0 \\
\hline
\end{tabular}

TABLE IV C

HELPFULNESS OF PEOPLE TALKED TO

MARRIAGE \& FAMILY COUNSELOR

Surveyed Group Served Group

Number Percent Number Percent

\begin{tabular}{llrrr} 
Helpful & 6 & 85.7 & 3 & 30.0 \\
Not Helpful & 1 & 14.3 & 2 & 20.0 \\
Not Sure & 0 & $-0-$ & 4 & 40.0 \\
Not Rated On & 0 & $-0-$ & 1 & 10.0 \\
$\quad$ Helpfulness & & & & \\
Total & 7 & 100.0 & 10 & 100.0 \\
\hline
\end{tabular}


TABLE IV D

HELPFULNESS OF PEOPLE TALKED TO SOCIAL WORKER

Surveyed Group Served Group

Number Percent Number Percent

\begin{tabular}{llccc} 
Helpful & 3 & 60.0 & 5 & 71.4 \\
Not Helpful & 1 & 20.0 & 1 & 14.3 \\
Not Sure & 1 & 20.0 & 1 & 14.3 \\
Not Rated on & 0 & $-0-$ & 0 & $-0-$ \\
Helpfulness & & & & \\
Total & 5 & 100.00 & 7 & 100.0 \\
\hline
\end{tabular}

TABLE IV E

HELPFULNESS OF PEOPLE TALKED TO ATTORNEY

\begin{tabular}{lrrrr} 
& \multicolumn{2}{c}{ Surveyed Group } & & \multicolumn{2}{c}{ Served Group } \\
\cline { 3 - 5 } & Number & Percent & Number & Percent \\
\hline Helpful & 18 & 69.2 & 25 & 48.1 \\
Not HelpfuI & 4 & 15.4 & 7 & 13.5 \\
Not Sure & 4 & 15.4 & 12 & 23.1 \\
Not Rated On & 0 & $-0-$ & 8 & 15.4 \\
$\quad$ Helpfulness & & & & \\
Total & 26 & 100.0 & 52 & 100.0 \\
\hline
\end{tabular}

TABLE IV F

HELPFULNESS OF PEOPLE TALKED TO FAMILY DOCTOR

Surveyed Group Served Group

Number Percent Number Percent

\begin{tabular}{lrrrr} 
Helpful & 9 & 81.8 & 10 & 52.6 \\
Not Helpful & 1 & 9.1 & 2 & 10.5 \\
Not Sure & 1 & 9.1 & 5 & 26.3 \\
Not Rated On & 0 & $-0-$ & 2 & 10.5 \\
Helpfulness & & & & \\
Total & 11 & 100.0 & 19 & 99.9 \\
\hline
\end{tabular}


TABLE IV G HELPFULNESS OF PEOPLE TALKED TO
CLERGYMAN

\begin{tabular}{lccccc} 
& \multicolumn{2}{c}{ Surveyed Group } & & \multicolumn{2}{c}{ Served Group } \\
\cline { 2 - 3 } \cline { 5 - 5 } & Number & Percent & Number & Percent \\
\hline Helpful & 13 & 92.9 & 16 & 64.0 \\
Not Helpful & 0 & $-0-$ & 3 & 12.0 \\
Not Sure & 1 & 7.1 & 3 & 12.0 \\
Not Rated On & 0 & $-0-$ & 3 & 12.0 \\
Helpfulness & & & & \\
Total & 14 & 100.0 & 25 & 100.0 \\
\hline
\end{tabular}

TABLE IV H

HELPFULNESS OF PEOPLE TALKED TO RELATIVES

Surveyed Group Served Group

Number Percent Number Percent

\begin{tabular}{lrrrr} 
Helpful & 39 & 78.0 & 29 & 51.8 \\
Not Helpful & 7 & 14.0 & 13 & 23.2 \\
Not Sure & 3 & 6.0 & 11 & 19.6 \\
Not Rated on & 1 & 2.0 & 3 & 5.4 \\
Helpfulness & & & & \\
Total & 50 & 100.0 & 56 & 100.0 \\
\hline
\end{tabular}

TABLE IV I

HELPFULNESS OF PEOPLE TALKED TO FRIENDS

Surveyed Group .. Served Group

Number Percent Number Percent

\begin{tabular}{lrrrr} 
Helpful & 33 & 78.6 & 6 & 46.2 \\
Not Helpful & 8 & 19.0 & 2 & 15.4 \\
Not Sure & 1 & 2.4 & 1 & 7.7 \\
Not Rated On & 2 & 4.8 & 4 & 30.8 \\
$\quad$ Helpfulness & & & & \\
Total & 44 & 100.0 & 13 & 100.1 \\
\hline
\end{tabular}


TABLE IV J

HELPFULNESS OF PEOPLE TALKED TO
OTHER

Surveyed Group Served Group

Number Percent Number Percent

\begin{tabular}{llcrr} 
Helpful & 5 & 71.4 & 7 & 58.3 \\
Not Helpful & 1 & 14.3 & 1 & 8.3 \\
Not Sure & 1 & 14.3 & 2 & 16.7 \\
Not Rated On & 0 & $-0-$ & 2 & 16.7 \\
$\quad$ Helpfulness & & & & \\
Total & 7 & 100.0 & 12 & 100.0 \\
\hline
\end{tabular}

TABLE IV K

HELPFULNESS OF PEOPLE TALKED TO

NO ONE AND NO RESPONSE

Surveyed Group

Percent

of Total

Number Respondents

\begin{tabular}{cl} 
Served Group \\
& $\begin{array}{l}\text { Percent } \\
\text { Of Total }\end{array}$ \\
Number $\quad$ Respondents \\
\hline
\end{tabular}

40

28.8

\begin{tabular}{lcccc}
$\begin{array}{l}\text { Talked To } \\
\text { No One }\end{array}$ & 32 & 28.1 & 40 & 28.8 \\
No Response & 2 & 1.8 & 7 & 5.0 \\
\hline
\end{tabular}

TABLE IV L

HELPFULNESS OF PEOPLE TALKED TO

TOTAL RESPONSES

Surveyed Group Served Group

Number Percent Number Percent

$\begin{array}{lrrrr}\text { Helpful } & 142 & 78.5 & 113 & 52.8 \\ \text { Not Helpful } & 23 & 12.7 & 37 & 17.3 \\ \text { Not Sure } & 13 & 7.1 & 40 & 18.7 \\ \text { Not Rated On } & 3 & 1.7 & 24 & 11.2 \\ \quad \text { Helpfulness } & & & & \\ \text { Total } & 181 & 100.0 & 214 & 100.0\end{array}$

Responses 
Due to the small number of respondents, chi squares could not appropriately be calculated regarding the helpfulness of individual categories of people talked to. However, overal1, the Surveyed Group were more likely to have found the people they talked to positively helpful $\left(\mathrm{df}=1, \mathrm{x}^{2}=17.802\right.$, level of confidence $\left.=.001\right)$. In calculating this statistic, responses of Not Helpful and Not Sure were aggregated into a single group of those not positively helpful and compared with the Helpful responses. A chi square was also calculated comparing only those responding Not Helpful with those responding Helpful. In this case, the Surveyed Group again were more likely to regard people talked to as being Helpful $\left(\mathrm{df}=1, \mathrm{x}^{2}=5.868\right.$, level of confidence $\left.=.02\right)$.

The picture that emerges from these data is that the Surveyed and Served Groups were equally as likely to have talked to most of the categories of people listed in the survey instruments (with the exception of friends and attorneys) and that the Served Group was less likely to have found talking to these people to be helpful. Further, the Served Group was also less likely to find their friends and attorneys to be helpful (based on comparisons of ratios calculated for individual categories of people talked to) and were slightly, though probably not significantly, more likely to find social workers helpful.

The authors suggest that the most probable reason for the Served Group responding that, overall, they were less likely to find the people talked to helpful is that the very fact that they found other people less than helpful was a motivating factor in their coming to the Family Court Service. That is, if the Served Group had found talking to other 
people helpful, they would probably not have needed to come to the Family Court Service for assistance.

\section{SECTION VI: SEX}

There were 61 males and 53 females in the Surveyed Group, and there were 75 males and 64 females in the Served Group for a total of 253 respondents. At the .05 level of confidence, there was no significant difference between the Surveyed and the Served Group $\left(\mathrm{d} f=1, \mathrm{X}^{2}=.003\right)$.

One would expect no significant difference in ratios of male to female in these two groups in that in obtaining the IDCAP sample, efforts were made to involve both petitioner and respondent to the dissolution proceedings in the survey and in the Agency efforts were made (and are made) to involve both petitioner and respondent in counseling.

\section{SECTION VII: NUMBER OF CHILDREN}

The number of children in both groups ranged from one through seven with a median category in both cases of two (Surveyed $=2.36$, Served $=2.40)$. Table $V$ shows the distribution of each group. At the .05 level of confidence, there was no significant difference between these two group in regard to number of children $\left(d f=3, x^{2}=2.708\right)$. 
TABLE V

NUMBER OF CHILDREN

Surveyed Group

Served Group

\begin{tabular}{lcrrrrr} 
Number & Number & Percent & $x^{2}$ & Number & Percent & $x^{2}$ \\
\hline & 39 & 34.2 & .002 & 47 & 33.8 & .001 \\
One & $50^{*}$ & 43.9 & .152 & $55^{*}$ & 39.6 & .125 \\
Two & 14 & 12.3 & 1.084 & 27 & 19.4 & .889 \\
Three & 11 & 9.7 & .250 & 10 & 7.1 & .205 \\
Four & & & & & & \\
$\quad$ Seven & 114 & 100.1 & & 139 & 99.9 &. \\
Total & & & & & &
\end{tabular}

*Intra-group

Median

These data do not differ significantly from the Clackamas County average of 2.3 children per family (U.S. Bureau of Census, 1972). Therefore, the number of children is neither a predictor of divorce nor of Service use.

\section{SECTION VIII: EDUCATION}

The range of years of education was divided into five subgroups: 1-11 years, 12 years, 13-15 years, 16 years, and 17 or more years. The median number of years for the Surveyed Group was 13.12 years and for the Served Group it was 12.75. There was no significant difference between the groups $\left(d f=4, x^{2}=7.78\right)$. Table VI shows the distribution of number of years of education. 
TABLE VI

YEARS OF EDUCATION

Surveyed Group

Served Group

Years Number Percent Chi Squares Number Percent Chi Squares

\begin{tabular}{lrrrrrr}
$1-11$ & 18 & 15.8 & .003 & 22 & 15.8 & .002 \\
12 & 37 & 32.5 & 2.108 & $61 *$ & 43.9 & 1.686 \\
$13-15$ & $37 *$ & 32.5 & .514 & 37 & 26.6 & .411 \\
16 & 10 & 8.8 & .791 & 7 & 5.0 & .633 \\
17 or more & 11 & 9.6 & .773 & 8 & 5.8 & .619 \\
No response & 1 & .9 & & 4 & 2.9 & \\
Total & 114 & 100.1 & & 139 & 100.0 & \\
\hline
\end{tabular}

*Intra-group

median category

These findings are comparable to the median education level of Clackamas County as a whole (12.4 years of education). However, the Surveyed Group indicated a median level of educational attainment of .72 years more than the County level. The Served Group was within . 35 years of the County median. Therefore, education is a predictor neither of divorce nor of Service used.

\section{SECTION IX: REFERRAL SOURCES}

Fifty-nine percent of the respondents were referred to the Agency by attorneys. This is by far the most frequent source of referrals. In descending order, other referral sources were: court (13.7\%), unspecified others (10.8\%), self (5.7\%), and prior clients $(3.6 \%)$. There were no responses of referrals from clergy, physicians, or from the schools. In two cases clients received referrals from more than one source, so the total number of responses is greater than the total number of served respondents. E1ght and..s1x-tenths percent of the 
respondents did not indicate any referral source. Table VII shows the response of the Served Group to the question of referral source.

\section{TABLE VII}

REFERRAL SOURCES: SERVED GROUP

\begin{tabular}{lrr}
\multicolumn{1}{c}{ Source } & Number & Percent \\
\hline & 82 & 59.0 \\
Attorney & 19 & 13.7 \\
Court & 15 & 10.8 \\
Other (unspecified) & 8 & 5.7 \\
Self & 5 & 3.6 \\
Prior Client & 0 & $-0-$ \\
Clergy & 0 & $-0-$ \\
Physicians & 0 & $-0-$ \\
Schools & 12 & 8.6 \\
No Response & 141 & 101.4 \\
Total & & \\
\hline
\end{tabular}

It is not surprising that a majority of referrals to the Family Court Service come from attorneys and the court. Support from the legal system is essential to the functioning of the Family Court Service in that attorneys and the court have been the traditional resource for people needing assistance with their separation and divorce. The Family Court Service has, in fact, focused most of its public relations efforts on these resources.

In summary, the findings of this study indicate that the people served by the Family Court Service were very similar to those surveyed by the IDCAP study in regard to employed income, sex, number of children; and education. They were slightly different in regard to age (being older) and number of years married (being married 1onger). The Served Group was also less likely to have discussed with friends the problems leading to their filing for divorce and more likely to have 
discussed them with attorneys, the people most likely to have referred this group to the Family Court Service. 


\section{CHAPTER IV}

\section{DISCUSSION}

In proposing this study the authors stated two purposes: 1) to determine whether the Agency was serving its target population (those people it was designed to serve), and 2) to provide a sociodemographic data base for a research project which the Agency is planning to begin July $1,1979$.

The authors have previously suggested that the target group would be comparable to the Surveyed Group, on which need for the Agency was based. Therefore, insofar as the Served Group is comparable to the Surveyed Group, it may also be comparable to the target group.

As the data have demonstrated above, the Surveyed and Served Groups are, indeed, comparable on the variables of sex, number of children, employed income, and education. There is no statistically significant difference between the two groups on these four variables. Therefore, none of these variables are to be perceived as indicators of use of the Agency's services.

The Surveyed and Served Groups did, however, differ significantly on the variables of age, length of marriage, and people talked to. As discussed above, the authors reason that while the differences in age and length of marriage were statistically significant, they are effectively quite smal1--the Served Group being 3.2 years older and married 1.3 years longer than the Surveyed Group. The authors further reason 
that this difference, then, does not interfere with the Agency's serving its target group.

The third significant variable was people talked to. There were three significant sub-variables of people talked to: attorneys, friends, and perceived helpfulness of people talked to. The Served Group were more likely to have talked to attorneys and less likely to have talked to friends. Further, they were less likely to have found talking to people to have been helpful.

The authors reason that the Served Group may be experiencing greater conflict in divorce and therefore be more likely to talk to an attorney and to seek services of the Agency in resolving these conflicts, since one of the Agency services is divorce mediation. Persons who were experiencing little or no conflict in the divorce process might choose to file their own divorce papers and not engage the services of an attorney. Further, clients may seek Agency services for the very reason that they did not find that the people they talked to were helpful. If these people had been helpful, clients need not have sought further help elsewhere. And finally, the Served Group was more likely to have talked to attorneys who, while they were perceived as not being helpful, were in fact the most common referral source for the Agency.

The relationship between the last three factors might be, then, that people experiencing greater conflict in divorce are less likely to talk with their friends about it, are less likely to find it helpful to talk to people about their conflicts and are, therefore, more likely to seek help from an attorney who is, in turn, most 1ikely to be the Agency's referral source. 
While these last findings indicate that the Agency may not be serving a group comparable to the Surveyed Group, the authors contend that in this instance, too, the results do not indicate that it is not serving its target group. In that the Agency is serving a group which may be experiencing greater conflict in divorce and is certainly finding the people it talks to less than helpful, the Agency is serving its target group of people in need of assistance in dealing with the conflicts and issues in divorce.

Finally, while there were few and small sociodemographic differences between the Surveyed and Served Groups, provision of this information on the Served Group provides the requested data base for the Agency's proposed continuing research efforts. 


\section{A SELECTED BIBLIOGRAPHY}

Borr, Kenneth W., Parental Perception of Behavioral Changes in Children Following Divorce, 1978, Unpublished Masters of Social Work Practicum, Portland State University.

Brown, C.A., Feldberg, R., Fox, E.M., \& Kohen, J., "Divorce: Change of a New Lifetime", The Journal of Social Issues, 1976, XXXII.

Campbe11, A., Converse, P.E., \& Rodgers, W., The Quality of American Life: Perceptions, Evaluations, and Satisfactions, 1976, New York: Russel1 Sage Foundation.

Campbe11, Donald T., \& Stanley, Julian C., Experimenta1 and QuasiExperimental Designs for Research, 1963, Chicago: Rand McNally College Publishing.

Cavanagh, R.C., \& Rhode, D.L., "The Unauthorized Practice of Law and Pro Se Divorce: An Imperican Analysis", The Yale Law Journal, 1976, LXXXVI, 104-184.

Cohen, S., Divorce: Its Impact on Parents and Children, February, 1978, Unpublished Paper Presented at the National Institute of Mental Health Symposium on Divorce Research, Washington, D.C.

Coogler, O.J., "Changing the Lawyer's Role in Matrimonial Practice", Conciliation Courts Review, 1977, XV, 1-8.

Despert, J.L., Children of Divorce, 1953, Garden City, New York: Doubleday.

Gilbert, Neil, \& Specht, Harry, Dimensions of Social Welfare Policy, 1974, Englewood Cliffs, New Jersey: Prentice-Hall, Inc.

Goode, W.J., Women in Divorce, 1956, New York: Free Press.

Gurin, G., Veroff, J., \& Field, S., Americans View Their Mental Health, 1960, New York: Basic Books.

Harrington, Michae1, The Other America, 1962, New York: MacMillan, 82-88.

Hatry, Harry P., Winnie, Robert E., \& Fisk, Donald M., Practucal Program Evaluation for State and Local Government officials, 1973, Washington, D.C.: The Urban Institute:

Hetherington, E.M., Cox, M., \& Cox, R., "Divorced Fathers", Family Coordinator, 1976, XXV, 417-428. 
Jones, C.A., Gordon, N.M., \& Sawhill, I.V., Child Support Payments in the United States, 1976, Washington, D.C.: The Urban Institute.

Jones, F. Nolan, "The Impact of Divorce on Children", Conciliation Courts Review, 1977, XV, 25-30.

Kerlinger, Fred N., Foundations of Behavioral Research, 1964, 1973, New York: Holt, Rinehart and Winston, Inc.

Kitson, G.C., \& Sussman, M.B., "The Impact of Divorce on Adults", Conciliation Courts Review, 1977, XV, 20-25.

Kresse1, K., Deutsch, M., Jaffe, N., Tuchman, B., \& Watson, C., "Mediated Negotiations in Divorce and Labor Disputes", Conciliation Courts Review, 1977, XV, 9-12.

Kressel, K., Lopez-Morillas, M., Weinglass, J., \& Deutsch, M., "Professional Intervention in Divorce: A Summary of the Views of Lawyers, Psychotherapists, and Clergy", Journal of Divorce, 1978, II, $119-155$.

Landis, Judson, "The Trauma of Children When Parents Divorce", Marriage and Family Living, 1960, XXII, 7-13.

Lee, Barbara E., \& Watne, Patricia E., A Consumer Evaluation of the Clackamas County Family Court Service, 1978, Unpublished Masters of Social Work Practicum, Portland State University.

Lightman, E.S., \& Irving, H.H., "Conciliation and Arbitration in Family Disputes", Conciliation Courts Review, 1976, XIV, 12-21.

Moles, Oliver, Hess, Robert, \& Fascione, Daniel. "Who Knows Where to Get Public Assistance?", Welfare in Review, September/October 1968, Vo1. VI, No. V, HV85.A391.

McDermott, John F., "Parental Divorce in Early Childhood", American Journal of Psychiatry, 1968, CXXIV, 1424-1432.

McDermott, John F., "Divorce and Its Psychiatric Sequalae in Children", Archives of General Psychiatry, 1970, XXIII, 421-427.

Nachmias, David, Public Policy Evaluation, 1979, New York: St. Martin's Press.

Nye, Ivan, "Child Adjustment in Broken and in Unhappy, Unbroken Homes", Marriage and Family Living, 1957, XIX, 356-361.

Piven, Francis Fox, \& Cloward, Richard, Regulating the Poor: The Functions of Public Welfare, 1971, New York: Pantheon Books, 147-182.

Udry, J. Richard, The Social Context of Marriage, (2nd edition), 1971, New York: J.B. Lippincott Company. 
U.S. Bureau of Census 1972, Census of Population and Housing: 1970, 1970 Census of Population and Housing, Portland, Oregon Washington, S.M.S.A., PHC (1) - 165, Washington, D.C., U.S. Government Printing office.

Wallerstein, Judith S., \& Kelly, Joan Berlin, "The Effects of Parental Divorce: The Adolescent Experience", The Child in His Family: Children at Psychiatric Risk, 1974, New York: Wiley and Sons

Wallerstein, Judith S., \& Kelly, Joan Berlin, "The Effects of Parental Divorce: Experiences of the Pre-School Child", Journal of Child Psychiatry, 1975, XIV, 600-616.

Wallerstein, Judith S., \& Kelly, Joan Berlin, "The Effects of Parental Divorce: Experiences of Children in Later Latency", American Journal of Orthopsychiatry, 1976, XLVI, 256-269.

Wallerstein, Judith S., \& Kelly, Joan Berlin, "Divorce Counseling: A Community Service for Families in the Midst of Divorce", American Journal of Orthopsychiatry, 1977, XLVII, 23-29.

Warheit, George J., Bell, Roger A., \& Schwab, John J., Needs Assessment Approaches: Concepts and Methods, 1977, Washington, D.C., U.S. Government Printing Office, Pub. 非 (ADM) 77-42.

Warwick, Donald P., \& Lininger, Charles A., The Sample Survey: Theory and Practice, 1975, New York: McGraw-Hill, Co.

Weiss, R.S., Marital Separation, 1975, New York: Basic Books.

Weiss, R.S., "The Emotional Impact of Marital Separation", Journal of Social Issues, 1976, XXXII, 135-145.

Westman, J.D., "The Role of Child Psychiatry in Divorce", Archives of General Psychiatry, 1970, XXIII, 416-420. 
DATA COLLECTION SCHEDULE

1st Marriage

1. Case \#

2. Mo

Fa

3. Age

4. Length of Marriage

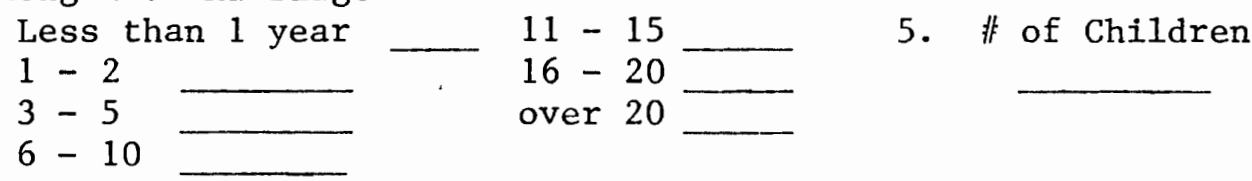

6. Education (Highest Completed) $1-11$ $13-15+16 \_17+$

12

7. Employed Yes ___ No ___ If Yes F.T.___ P.T.

8. Gross Monthly Income

$\begin{array}{ll}\text { Less Than } 200 \longleftarrow & 10-1199 \\ 2-399 & 12-1399 \\ 3-599 & 14-1599 \\ 6-799 & 16-1799 \\ 8-999 & 1800 \text { or over }\end{array}$

9. Who was Talked With? Helpful Not Helpful Not Sure Relatives

- Clergyman

- Family Doctor

- Attorney

- Psychiatrist

- Psychologist

- Marriage \&

Family Counselor

_ Social Worker

- other

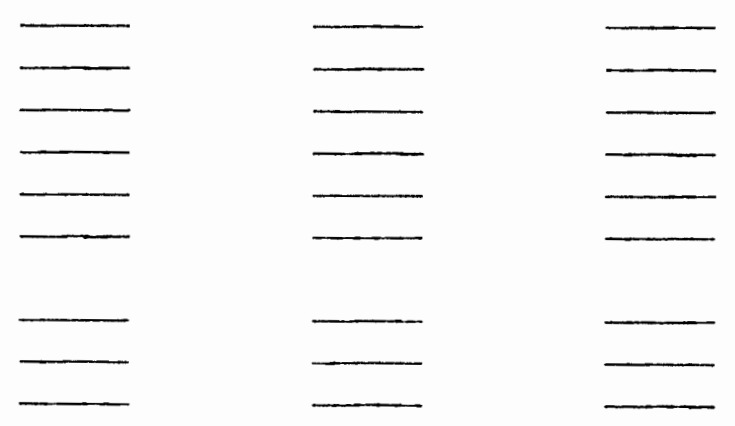

10. Referred by:

Self

Lawyer

Court

Prior Client

Clergyman

Schoo1

Physician

Other 